\title{
Whole-Cell Matrix-Assisted Laser Desorption Ionization Time-Of-Flight Mass Spectrometry Applications in Medical Microbiology
}

\section{Szabados Florian*}

${ }^{1}$ Institute for Hygiene and Microbiology, Dept. of Medical Microbiology, University Bochum, Germany

Matrix assisted laser desorption/ionisation time of flight mass spectrometry (MALDI-TOF MS) has been introduced several years ago as a new method for bacterial identification $[1,2]$. Since a couple of years a variety of studies have been investigated the accuracy of a MALDI-TOF MS-based identification of grown colonies $[3,4,5,6]$. Since proteomic profiles were compared to a database, the accuracy of the identification results on the database used $[7,8]$. For most identification approaches, protein peaks in the mass-to charge ratio of 2000 to 10000 Da were used, most of them thought to represent ribosomal protein peaks. The results of commercial databases are believed to be very high in accuracy. Nevertheless, an independent protein profile deposition possibility and further optimization strategies $[9,10]$ are desirable in order to improve these databases independently of the manufacturer. Therefore studies with focus on the accuracy of identification of rare bacteria, fungi and other organisms are highly appreciated.

The direct identification of bacteria from materials such as urine and blood culture has also been published and introduced in some diagnostic laboratories $[11,12,13,14]$. Even though the accuracy seems to be lower compared to that of direct identification, studies investigating the direct identification approach from various clinical specimens are welcome.

A few "proof of principle" studies have been published with regard to MALDI-TOF MS and an epidemiological application $[15,16]$. In addition, other techniques, such as Raman-spectroscopy $[17,18]$ or the PlexID ${ }^{\infty}$ system, have been described. The accuracy and more important, the possibilities and limitation has been often only scarcely investigated.

Whether these technologies are suitable to identify certain pathogenicity factors $[19,20,21]$ or resistance $[22,23,24]$ is current ongoing research in medical microbiology. Since any kind of information beside species information would have a great impact on infectious diseases treatment and therapy; this will be a challenge to solve in the next years and in addition, the detection of outstanding resistant organisms, such as carbapenemase -producing enterobacteriaceae and other threat of the next century [25]. Methods that directly identify underlying resistance mechanisms are needed and will be of peculiar importance.

Studies with a clear hypothesis and a well-organized study structure are highly appreciated even in cases of a negative result.

\section{References}

1. Krishnamurthy T, Ross PL (1996) Rapid identification of bacteria by direct matrix-assisted laser desorption/ionization mass spectrometric analysis of whole cells. Rapid Commun Mass Spectrom 10: 1992-1996.

2. Fenselau C, Demirev PA (2001) Characterization of intact microorganisms by MALDI mass spectrometry. Mass Spectrom Rev 20: 157-171.

3. Seng P, Drancourt M, Gouriet F, La Scola B, Fournier PE, et al. (2009) Ongoing revolution in bacteriology: routine identification of bacteria by matrix-assisted laser desorption ionization time-of-flight mass spectrometry. Clin Infect Dis 49: 543-551.

4. Szabados F, Woloszyn J, Richter C, Kaase M, Gatermann S (2010) Identification of molecularly defined Staphylococcus aureus strains using matrix-assisted laser desorption/ionization time of flight mass spectrometry and the Biotyper 2.0 database. J Med Microbiol 59: 787-790.

5. Hsieh SY, Tseng CL, Lee YS, Kuo AJ, Sun CF, et al. (2008) Highly efficient classification and identification of human pathogenic bacteria by MALDI-TOF MS. Mol Cell Proteomics 7: 448-456.

6. Mellmann A, Cloud J, Maier T, Keckevoet U, Ramminger I, et al. (2008) Evaluation of matrix-assisted laser desorption ionization-time-of-flight mass spectrometry in comparison to 16S rRNA gene sequencing for species identification of nonfermenting bacteria. J Clin Microbiol 46: 1946-1954.

7. Carbonnelle E, Beretti JL, Cottyn S, Quesne G, Berche P, et al. (2007) Rapid identification of Staphylococci isolated in clinical microbiology laboratories by matrix-assisted laser desorption ionization-time of flight mass spectrometry. $J$ Clin Microbiol 45: 2156-2161

8. Dupont C, Sivadon-Tardy V, Bille E, Dauphin B, Beretti JL, et al. (2010) Identification of clinical coagulase-negative staphylococci, isolated in microbiology laboratories, by matrix-assisted laser desorption/ionization-time of flight mass spectrometry and two automated systems. Clin Microbiol Infect 16: 998-1004.

9. Szabados F, Tix H, Anders A, Kaase M, Gatermann SG, et al. (2012) Evaluation of species-specific score cutoff values of routinely isolated clinically relevant bacteria using a direct smear preparation for matrix-assisted laser desorption/ ionization time-of-flight mass spectrometry-based bacterial identification. Eur $J$ Clin Microbiol Infect Dis 31: 1109-1119.

10. Richter C, Hollstein S, Woloszyn J, Kaase M, Gatermann S, et al. (2012) Evaluation of species-specific score cut-off values of various staphylococci species using a MALDI Biotyper-based identification. J Med Microbiol [Epub ahead of print]

11. Stevenson LG, Drake SK, Murray PR (2010) Rapid identification of bacteria in positive blood culture broths by matrix-assisted laser desorption ionization-time of flight mass spectrometry. J Clin Microbiol 48: 444-447.

12. Prod'hom G, Bizzini A, Durussel C, Bille J, Greub G (2010) Matrix-assisted laser desorption ionization-time of flight mass spectrometry for direct bacterial identification from positive blood culture pellets. J Clin Microbiol 48: 1481-1483.

13. Szabados F, Michels M, Kaase M, Gatermann S (2011) The sensitivity of direct identification from positive BacT/ALERT ${ }^{\mathrm{TM}}$ (bioMerieux) blood culture bottles by matrix-assisted laser desorption ionization time-of-flight mass spectrometry is low. Clin Microbiol Infect 17: 192-195.

14. La Scola B, Raoult D (2009) Direct identification of bacteria in positive blood culture bottles by matrix-assisted laser desorption ionisation time-of-flight mass spectrometry. PLoS One 4: e8041.

15. Bernardo K, Pakulat N, Macht M, Krut O, Seifert H, et al. (2002) Identification and discrimination of Staphylococcus aureus strains using matrix-assisted laser desorption/ionization-time of flight mass spectrometry. Proteomics 2: 747-753.

*Corresponding author: F Szabados, Institute for Hygiene and Microbiology, Department for Medical Microbiology, University Bochum, National Reference Laboratory for Multidrug-resistant Gram-negative Bacteria for Germany,

Universitätsstraße 150, Bochum, Germany, Tel : +49-(0)234-32-26467; Fax: +49(0)234-32-14197; E-mail: Florian.szabados@rub.de

Received July 17, 2012; Accepted July 30, 2012; Published August 02, 2012

Citation: Florian S (2012) Whole-Cell Matrix-Assisted Laser Desorption Ionization Time-Of-Flight Mass Spectrometry Applications in Medical Microbiology. J Med Microb Diagn 1:e111. doi:10.4172/2161-0703.1000e111

Copyright: (c) 2012 Florian S. This is an open-access article distributed under the terms of the Creative Commons Attribution License, which permits unrestricted use, distribution, and reproduction in any medium, provided the original author and source are credited. 
Citation: Florian S (2012) Whole-Cell Matrix-Assisted Laser Desorption Ionization Time-Of-Flight Mass Spectrometry Applications in Medical Microbiology. J Med Microb Diagn 1:e111. doi:10.4172/2161-0703.1000e111

16. Wolters M, Rohde H, Maier T, Belmar-Campos C, Franke G, et al. (2011) MALDI-TOF MS fingerprinting allows for discrimination of major methicillinresistant Staphylococcus aureus lineages. Int J Med Microbiol 301: 64-68.

17. Grun J, Manka CK, Nikitin S, Zabetakis D, Comanescu G, et al. (2007) Identification of bacteria from two-dimensional resonant-Raman spectra. Anal Chem 79: 5489-5493.

18. Jehlička J, Oren A, Ví-tek P (2012) Use of Raman spectroscopy for identification of compatible solutes in halophilic bacteria. Extremophiles 16: 507-514.

19. Bittar F, Ouchenane Z, Smati F, Raoult D, Rolain JM (2009) MALDI-TOF-MS for rapid detection of staphylococcal Panton-Valentine leukocidin. Int J Antimicrob Agents 34: 467-470.

20. Szabados F, Becker K, von Eiff C, Kaase M, Gatermann S (2011) The matrixassisted laser desorption/ionisation time-of-flight mass spectrometry (MALDITOF MS)-based protein peaks of 4448 and $5302 \mathrm{Da}$ are not associated with the presence of Panton-Valentine leukocidin. Int J Med Microbiol 301: 58-63.

21. Dauwalder O, Carbonnelle E, Benito Y, Lina G, Nassif X, et al. (2010) Detection of Panton-Valentine toxin in Staphylococcus aureus by mass spectrometry directly from colony: time has not yet come. Int J Antimicrob Agents 36: 193194.

22. Shah HN, Rajakaruna L, Ball G, Misra R, Al-Shahib A, et al. (2011) Tracing the transition of methicillin resistance in sub-populations of Staphylococcus aureus, using SELDI-TOF Mass Spectrometry and Artificial Neural Network Analysis. Syst Appl Microbiol 34: 81-86.

23. Szabados F, Kaase M, Anders A, Gatermann SG (2012) Identical MALDI TOF MS-derived peak profiles in a pair of isogenic SCCmec-harboring and SCCmeclacking strains of Staphylococcus aureus. J Infect [Epub ahead of print].

24. Edwards-Jones V, Claydon MA, Evason DJ, Walker J, Fox AJ, et al. (2000) Rapid discrimination between methicillin-sensitive and methicillin-resistant Staphylococcus aureus by intact cell mass spectrometry. J Med Microbiol 49: 295-300.

25. Kaase M, Szabados F, Wassill L, Gatermann SG (2012) Detection of carbapenemases in Enterobacteriaceae by a commercial multiplex PCR. J Clin Microbiol 50: 3115-3118. 